\title{
Being Arjuna was Enriching, Being Eklavya is Enlightening!
}

\author{
Neha Chauhan ${ }^{1}$ \\ ${ }^{1}$ Department of Plastic Surgery, Chinmaya Mission Hospital, \\ $\mathrm{CMH}$ Road, Indiranagar, Bangalore, Karnataka, India
}

Indian J Plast Surg 2020;53:150-151

"Whether one moves slowly or with speed, one who is a seeker will be a finder"

- Rumi

It has been exactly 6.5 years since I completed my plastic surgery residency and exactly 6.5 years before that, I started on my journey of becoming a surgeon and later a plastic surgeon. And that makes it imperative to write on the above topic before I grow older and perhaps land up in the shoes of Dronacharya!

The 3-year period of surgical residency taught me how to hold the enigma called as scalpel, which had been an enigma to me since my MBBS (Bachelor of medicine and Bachelor of surgery) days, followed by the tricks of cutting and sewing until it became ingrained in my DNA and became as routine to me as my breathing. Conducting laparotomies were like opening Pandora's boxes, each time teaching something new and unforgettable. After my surgical residency, I did 6 months of senior residency in plastic surgery to evaluate if I really wanted to pursue a career in plastic surgery. The most interesting aspect of plastic surgery as a specialty was the freedom to make choices. Different people could have different options to treat the same defect and all of them could be equally good options. This aspect of plastic surgery impressed me the most and made me take plastic surgery entrance exams. This was followed by 3 years of plastic surgery residency which finally culminated into my becoming a plastic surgeon in July 2013. I have vivid memories of both my general surgery and plastic surgery residency. The 3-year plastic surgery residency was an action-packed period of attending to a myriad of cases including burns, trauma, microsurgery, oncosurgical reconstruction, maxillofacial injuries, craniofacial surgeries, congenital anomalies, hand surgeries, and a bit of cosmetic surgery. I am privileged to have completed my residency from an institute (Vardhaman Mahavir Medical College and Safdarjung hospital, New Delhi, India) where the workload was good and the teachers were excellent. I had the opportunity to observe most of the
Address for correspondence Neha Chauhan, MBBS, MS (General Surgery), MCh (Plastic Surgery), House No 286, Jal Vayu Vihar, Kamannahalli, Bangalore, Karnataka, 560043, India (e-mail:drnehac@gmail.com).

commonly encountered cases in plastic surgery along with some of the rarer ones that I may never again see in my practice. Life was overall good in a protected environment where I felt that having qualified the entrance exam it was my right to be taught. There was a sense of entitlement that came with the assumption that having qualified the entrance exam, I belonged to the institute which had the duty to nurture and bring out the best in me. The environment was friendly and protective at the same time. I would often single handedly venture into tough cases, as I knew that I had the firm backing of my teachers, accompanied by the belief that I was there to learn the tricks of the trade. I felt that even if there were slight under results or small errors, they were pardonable as I was a trainee. There was a feeling that it was the duty of the institution to provide us with enough skills, so that once we finish our residency, we could perform most of the surgeries independently. In short, I felt entitled to be taught during those three years of residency.

The few months after the residency went into euphoria and confusion at the same time. When initial attempts to get into any institution as a full-time employee failed and later personal commitments like childbirth made it difficult to pursue full time work, I chose freelancing. It gave me a major advantage of free and independent decision making along with independence of timings. But it also brought along the occasional challenges of managing tough/rare cases alone, cases that I hadn't seen or done before.

One such case that I encountered in the first year of my postresidency career was a male patient with right sided Poland's syndrome. Textbooks had little to offer except that latissimus dorsi (LD) was the preferred choice for reconstruction. I had successfully assisted and harvested LD flap multiple times in residency both as a free and a pedicle flap but here the question was of how to fix the muscle to the chest wall and sternum, so that it stays and doesn't cut through and retract toward the origin. Improper/inadequate fixation of the flap would be like sounding a death knell for
License terms

()(1) $\Theta \circledast$ 
my reconstruction. I hunted for answers in books and scholarly articles but found no advice that could give me practical tips on the same. I didn't want to lose an interesting case nor did I want to give the patient who had placed his entire trust on me, suboptimal result. The next step was to call and write to a few of my teachers but I could not get a response from them too as they had never encountered a male with Poland's syndrome. Next step was to step out of the comfort zone and find out the best and most experienced names in plastic surgery in the country and seek their guidance, even when I had personally known none of them prior to this. I wrote to 10 , got responses from 4 , while one of them actually answered in minute details what I had been seeking for since past couple of weeks since the time I had seen the patient. Weeks of sleepless days and nights finally gave way to a calm. I now had my solution at hand, I executed it to the hilt and got satisfactory results. This search of an answer to my question slowly transformed me from Arjuna to Eklavya. With this case, not only did I learn how to do a male Poland's syndrome reconstruction but also the very essential traits of getting out of the comfort zone, persevering until one found the right answer, being patient in seeking knowledge, not being baffled at not getting answers from all the people, even though they may be the experts in the field and of lowering of my ego. It also taught me humility, and grace. This was the first time I sought advice from the people whom I had never known but it broadened my perspective and made me a seeker. Now I seek advice as and when I need and don't stop until I get all my answers. While most of the times the people from whom I seek answers are senior to me, I no longer hesitate in seeking help/guidance from contemporaries and even junior colleagues who have gone in for specialized fellowships in respective fields.

From the brash and entitled Arjuna, I have become a calmer and humbler Eklavya ... The transition though initially bumpy has been an eye opener and journey has been thoroughly enlightening. I have learnt and continue learning much more as Eklavya than I could ever as Arjuna. And I'm extremely grateful to all those who have been Dronacharya to me post my residency!

PS: Arjuna, Eklavya, and Dronacharya are characters from the epic of Mahabharata. Arjuna was a royal prince of Hastinapur and had formal education from Guru Dronacharya, who was the teacher to royal princes. Eklavya on other hand was a tribal with keen interest in archery but could not be a student of guru Dronacharya who only taught the royal princes. So Eklavya made a mud statue of Dronacharya, considered it as live guru Dronacharya and started practicing archery in front of it, believing that guru Dronacharya himself was teaching him. Over course of time, Eklavya exceeded Arjuna in skills of archery before guru Dronacharya made him leave archery by asking for the thumb of his right hand as guru dakshina. The author has used the term of her being Arjuna for her "formal training"/residency and being Eklavya for her "informal training" postresidency from various sources.

\section{Financial Disclosures}

None.

\section{Conflict of Interest}

None declared. 